\section{Modelling the influence of crowd control railings on the Kiss nightclub evacuation}

\author{
Guilherme Günther Hennemann, ${ }^{1}$ \\ Augusto M. Gil, ${ }^{1}$ Fabrício L. Bolina, ${ }^{1}$ \\ Eduardo E.C. Rodrigues, ${ }^{1}$ \\ Bernardo F. Tutikian, ${ }^{1}$ \\ George C.B. Braga ${ }^{2}$ \\ ${ }^{1}$ Department of Civil Engineering, \\ University of Vale do Rio dos Sinos \\ São Leopoldo; ${ }^{2}$ Federal District Fire \\ Department, University of Brasília, \\ Brazil
}

\begin{abstract}
Fires in crowded gathering places such as nightclubs generate imminent risks to people's lives, as supported by historical facts. Building evacuation is defined as fundamental to prevent the occurrence of a tragedy. In the Kiss nightclub fire, many people could not reach the exit because of the controlling rails positioned in front of exit doors, as pointed-out by firefighters and survivors. This study aimed to evaluate the influence of these barriers in the escaping of Kiss nightclub, using computerassisted simulation. Four simulations were run, considering two types of capacity, each one with and without the rails. As preliminary analyses, the simulations presented a reduction of nearly $50 \%$ of the total time for the nightclub evacuation without the rails, confirming the barriers as a factor that considerably increased evacuation time of the nightclub occupants.
\end{abstract}

\section{Introduction}

Until the early 1970's, fire safety in Brazilian buildings was not treated with the necessary relevance. There was not a welldeveloped fire safety regulation, especially regarding emergency exits. ${ }^{1}$ Thus, high buildings were built without concerns on how people would escape in the occurrence of a fire. The fires in Andraus and Joelma buildings marked a paradigmatic change, leading to the development and improvement of the current regulation, such as ABNT NBR 9077 - Emergency exits. ${ }^{2}$

Fires in crowded gathering places such as nightclubs generate imminent risks to people's lives. Historical cases support this information, such as the fire at a nightclub in Buenos Aires and in Oakland, on 2004 and 2016, respectively. Both events support statistical data about the number of lives lost due to possible negligence towards the fire safety design. These facts emphasizes the importance of designing and constructing safe buildings, besides having them operating in such manner. In Brazil, the importance of fire safety has emerged after the Kiss nightclub fire, in the city of Santa Maria, Rio Grande do Sul state, which resulted in 242 deaths.

Similarities of Kiss nightclub fire to other disasters show up the importance to effective preventive measures, which can be accomplished through legislation and its application. ${ }^{3}$ Because of Kiss nightclub fire, a state law called Law Kiss was approved, implying changes in Brazilian fire safety regulation. However, Brazil has a big variety of fire safety regulations among all states, which could be improved by the creation of a national fire safety code. ${ }^{4}$

Escaping buildings safely is among the objectives required in a fire safety design, setting itself as a fundamental piece of the design. ${ }^{5}$ Brazilian standard, ABNT NBR $9077: 2001,{ }^{2}$ as well as the Technical Instruction $N^{0} 11$ of the São Paulo State Fire Department, ${ }^{6}$ present essential security conditions for passive protection, namely emergency exits. Both regulations present the procedure to calculate the maximum occupation, the maximum travel distance and the minimum width of escaping routes.

In addition to regulations, computeraided analyses can be used to assess the efficiency of exit designs at an optimal manner, according to a preset architectonical conception. Despite being difficult to predict people's behavior in emergency situations and, consequently, to evaluate the efficiency of emergency exits, ${ }^{7}$ the use of software tools that simulate escaping routes has become more frequent due to its closeness to reality. ${ }^{8}$

Studies have been developed based on continuous network models, such as Pathfinder. It uses a two-dimensional plane where occupants move through the building subjected to conditions like collision between occupants. ${ }^{9}$ Among evacuation studies using Pathfinder are a Subway station, ${ }^{10}$ a University library, ${ }^{11}$ a Road tunnel, ${ }^{12}$ and a Music festival, ${ }^{13}$ which is similar to a nightclub because of the gathering of very high number of people and the unfamiliar evacuation routes. Usually, default settings are used in evacuation models, but each simulation will have a user effect because of choices during the model calibration process. ${ }^{14}$

This study aimed to evaluate the influence of crowd controlling rails on the evacuation of Kiss nightclub using Pathfinder software. Several specialists gave their opinion on the influence of those barriers.
Correspondence: Guilherme Günther Hennemann, Department of Civil Engineering, University of Vale do Rio dos Sinos, Av. Unisinos 950, São João Batista, São Leopoldo, CEP 93022-750, Brazil.

Tel.: +55.51.3590.8887.

E-mail: guilhermeghennemann@gmail.com

Key words: Fire; Evacuation; Modelling; Nightclub evacuation.

Contributions: GH, modelling Kiss nightclub and manuscript writing, AG, FB, ER, BT, manuscript reviewing; GB, modelling support and manuscript reviewing.

Conflict of interests: the authors declare no potential conflict of interest.

Funding: the work was supported by the Technological Institute on Civil Construction Performance - itt Performance/UNISINOS.

Conference presentation: part of this paper was presented at the 4th Ibero-Latin American Congress on Fire Safety ( $4^{\circ}$ CILASCI), 2017 Oct 9-11, Recife, Brazil.

Received for publication: 12 December 2017. Revision received: 1 June 2018.

Accepted for publication: 7 June 2018.

This work is licensed under a Creative Commons Attribution 4.0 License (by-nc 4.0).

(C) Copyright G.G. Hennemann, et al., 2018

Licensee PAGEPress, Italy

Fire Research 2018; 2:49

doi:10.4081/fire.2018.49

The technical report made by the Council of Civil Engineering and Agronomy of Rio Grande do Sul state (CREA-RS) ${ }^{15}$ mentioned it as a factor that increased considerably the nightclub's evacuation time. Given the importance of emergency exits to this type of building and the constant search in this field for improvements towards user safety, four simulations were run, considering two types of capacity, each one with and without the rails.

\section{Building's evacuation}

Reaction to fire of building materials is characterized as one of the main causes of fire growth. The main factors that contribute to the outspread of panic and cause of deaths are the propagation of flames, release of smoke and toxic gases. ${ }^{16}$ In a fire, the smoke spread velocity can reach $2 \mathrm{~m} / \mathrm{s},{ }^{17}$ which can be faster than the walking speed of people in a crowded space..$^{9,18}$ Thus, controlling the fire reaction of coating materials 
is one of the factors that exerts most influence upon the composition of the time available for escape. ${ }^{19}$

Among the protective measures against fire, the emergency exit is a fundamental aspect of the design. ${ }^{5,20}$ To assure design effectiveness, it is necessary to understand human behavior in situations of emergency, which usually has slow reaction. ${ }^{21}$ Comprehending the evacuation is not a simple task though, as it requires a multidisciplinary study. ${ }^{22}$

Case studies concluded that evacuation is divided in two stages, the pre-evacuation and the movement one. ${ }^{22}$ The pre-evacuation stage covers the period between the time of ignition and the time a person or a group of people starts running away, being divided in three sub-stages. The time for detecting fire takes place in the first substage, followed by the time for file alarm (awareness) in the second sub-stage, and then the pre-movement time, that is, the time between the alarm and the decision to evaluate in the third sub-phase. ${ }^{19}$

During the pre-movement period, people tend to look for their personal belongings and alert others. After this time interval, the movement period starts and only ends when the last person has reached a safe place. ${ }^{7}$ Several factors impact evacuation time, such as people's behavior, the building design and the density of people within the rooms. ${ }^{22}$ Figure 1 presents the stages of the evacuation process and gives the result for total evacuation time. ${ }^{19}$

$$
T_{e s c}=t_{\text {det }}+t_{a}+t_{\text {pre }}+t_{e}
$$

where: $t_{d e t}=$ time of detenction; $t_{a}=$ time of alarm; $t_{\text {pre }}=$ pre-movement time; $t_{e}=$ time of evacuation; $t_{e s c}=$ total escape time.

The escape from nightclubs occurs more slowly due to peculiar conditions of the surroundings, such as strong flashing lights and loud music, as well as limited conditions of visibility and perception of calamities, aggravating the escape procedure. ${ }^{23}$ Besides, the evacuation of these places is made more difficult due to the high occupation rate, which offers high potential towards victimization.

\section{Materials and Methods}

This study consists in four computerassisted simulations of the Kiss nightclub evacuation. The first two simulated the nightclub under full capacity considering the dimensioning method required at the time of the disaster, as ABNT NBR 9077:2001 standard (691 people), with and without the metallic rails. The other two simulated the nightclub overcrowded (1061 people), with and without the metallic rails, considering that this was the maximum that the simulation could allocate within the area. Figure 2 presents an outline of simulations that were run.

\section{Kiss nightclub}

The nightclub was modelled in accordance with data found in journalistic articles and the technical report of CREA-RS, which may have been the main limiting factor of this study. ${ }^{15}$ The place had approximately $640 \mathrm{~m}^{2}$ of area and was classified as a crowd gathering place, Division F-6 by the current regulation in Rio Grande do Sul state. The calculation of the nightclub's maximum occupation capacity, considering the rooms for people accommodation and the support areas, resulted in 691 people. Thus, it would be required seven passage units, which were distributed in two doors placed side by side for the nightclub exiting.

The crowd control metallic rails behaved as obstruction elements towards the nightclub evacuation, as they reduced considerably the space available for escape. ${ }^{15}$ Therefore, these elements represented solid barriers in the simulations. Seeking a pattern, in both situations, the occupants were inserted by density within the spaces of the nightclub, without overlapping, i.e., the proportion of occupant in the nightclub room area were equal, only modifying the total number of occupants. The number of workers at the day of the incident is known and it was fixed for both simulations, as well as its distribution in the area of support. Figure 3 presents the modelling of the nightclub.

\section{Computer-assisted simulation}

The software used for modelling was Pathfinder, developed by Thunderhead Engineering, selecting the steering mode, which is an agent-based model. ${ }^{12}$ The steering mode uses the interaction between the environment and other occupants to move them, changing, for example, their path and velocity, which provides more realistic results. $^{24}$

The profile of the occupants was based on software's default and adjusted to represent better the real people that were there. The parameters of exit choice were also modified after many simulations to have more realistic results, increasing the global travel time cost factor and decreasing the current door preference and current room distance penalty. The velocity and the shoulder width were used as default, but the comfort distance was reduced to $0,08 \mathrm{~m}$ because of the emergency situation..$^{25}$

The pre-evacuation times were set following a uniform distribution between the nightclub rooms. It was considered that the

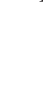

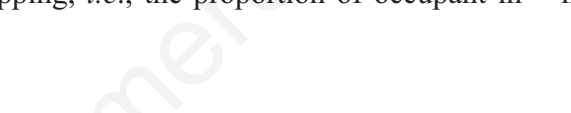

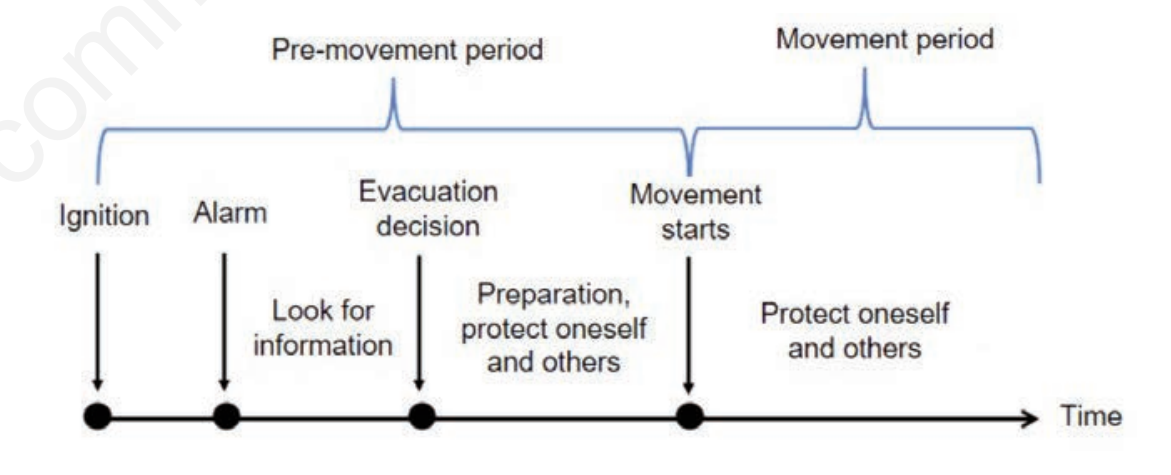

Figure 1. Steps of the evacuation process. 
people closer to the fire had shorter preevacuation times (10s), while those who were farther had longer pre-evacuation times (50s). These values were chosen from videos available on the Internet from the beginning of the fire and from survivor testimonies.

It should be noted that the software has limitations, like stuck occupants, who leave the area in a rational manner, without going over physical barriers, as occurs in real life. ${ }^{26}$ This limitation makes the evacuation slower, leading to conservative results.

\section{Results and Discussion}

The first result from the models created is the total evacuation time. Table 1 presents the escape time for the simulations that were run.

The influence of the rails could be noted, as it reduced total escape time by $49.98 \%$ for the nightclub with 691 people and $45.75 \%$ for the nightclub with 1061 people. This may have occurred due to the congestion of people as they crossed the small spaces between rails, as shown in Figure 4A, and because one of the rails were positioned in front of a door that led to the emergency exit of the nightclub. Figure
4B and $\mathrm{C}$ presents the density of the building after evacuation, emphasizing the disproportionality between escape routes with and without rails. This also confirmed the fact that the reduced width contributed to a more difficult passage of people, and that the emergency exit must have a continuous flow, with as little changes of direction as possible.

Journalistic articles and reports, as well as studies of the fire that took place in The Station Nightclub, ${ }^{27}$ in 2002, in the United States, indicates that the nightclub did not present survival conditions after $90 \mathrm{~s}$ due to the quick smoke propagation. According to the computer-assisted simulation, in the best evacuation scenario, namely when there were 691 people without the rails, the total escape time was estimated in 200 s. Hence, victims would probably have been made, as there is a difference of $110 \mathrm{~s}$ between the habitability of the nightclub and the evacuation from it. This confirms the importance of the correct application of coating materials as well as to increase the time available for evacuation. Figure 5A and $\mathrm{B}$ present the people density inside the building at 90 s of the evacuation, showing the worst escape condition and the best scenario simulated.

A linear evacuation trend is noticeable in both cases, as presented in Figure 6A and
B. There is only one way out of the nightclub, so people flowed through the same place. Figure 6A shows that people took longer to evacuate the building after $450 \mathrm{~s}$ because a line was formed between the rails, while other routes remained empty. This could be avoided if there were no rails in the nightclub.

Analyzing the evacuation from the dance floor struck by the fire, a reduction of 100 s was observed from the escape, com-

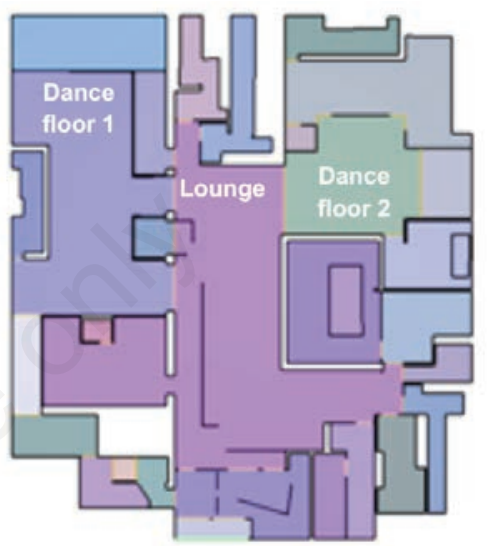

Figure 3. Kiss nightclub modeled.

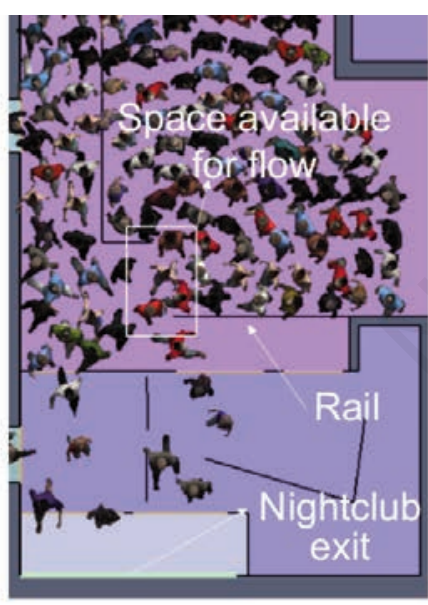

A

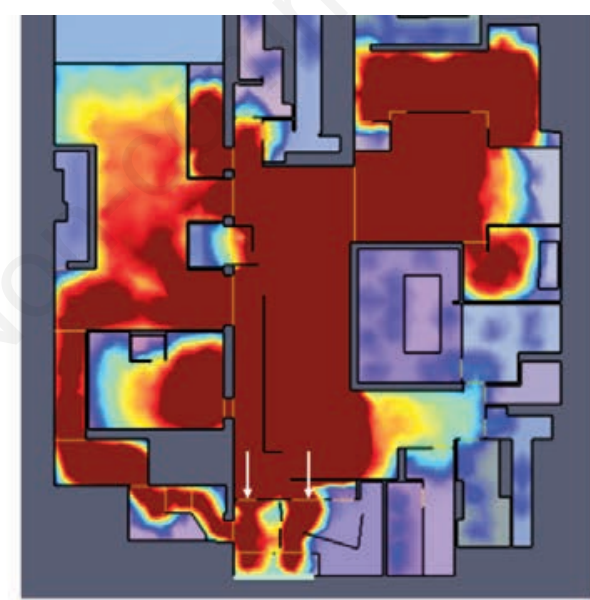

B

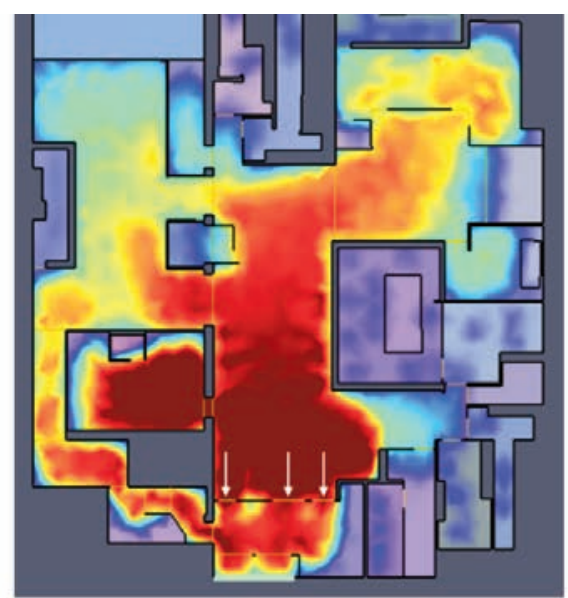

C

Figure 4. (A) Congestion of people and representation of rails. (B) Density of use of the building after evacuation: 1061 people with rails. (C) Density of use of the building after evacuation: 1061 people without rails

Table 1. Total evacuation times.

Evacuation time $(\mathrm{s})$
$\begin{aligned} & \text { With rails } \\ & \text { Nightclub with } 691 \text { people } \\ & \text { Without rails }\end{aligned}$


paring 1061 people with and without rails. Moreover, Figure 7A shows that some people passed by this dance floor again after 350 s (there is a peak right after this time), seeking a way out due to the wait time at the line formed between the rails of the lounge being long.

The simulation of 1061 people with rails also demonstrated that the dance floor 2 yielded the longest escape time. This dance floor was farther from the fire and the emergency exit, so it counted with longer pre-movement time. Besides, people escaped the building through the central lounge, an escape route with high occupation rates, which is unfavorable.

Figure 8 shows the longest nightclub evacuation times, represented by the dark red color. This fact confirms that emergency exits are needed on opposite facades of the building, as currently stated in the Technical Resolution $\mathrm{N}^{\mathrm{o}} 11$ - 2016 of the Fire
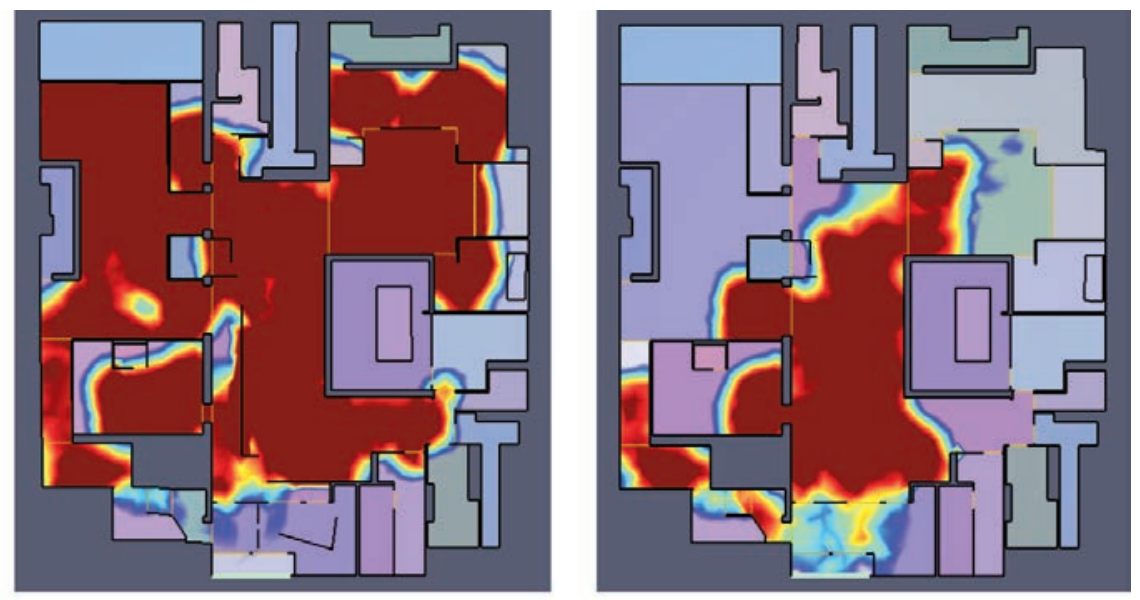

A

B

Figure 5. Density of the building at 90s. (A) 1061 people with rails; (B) 691 people without rails.
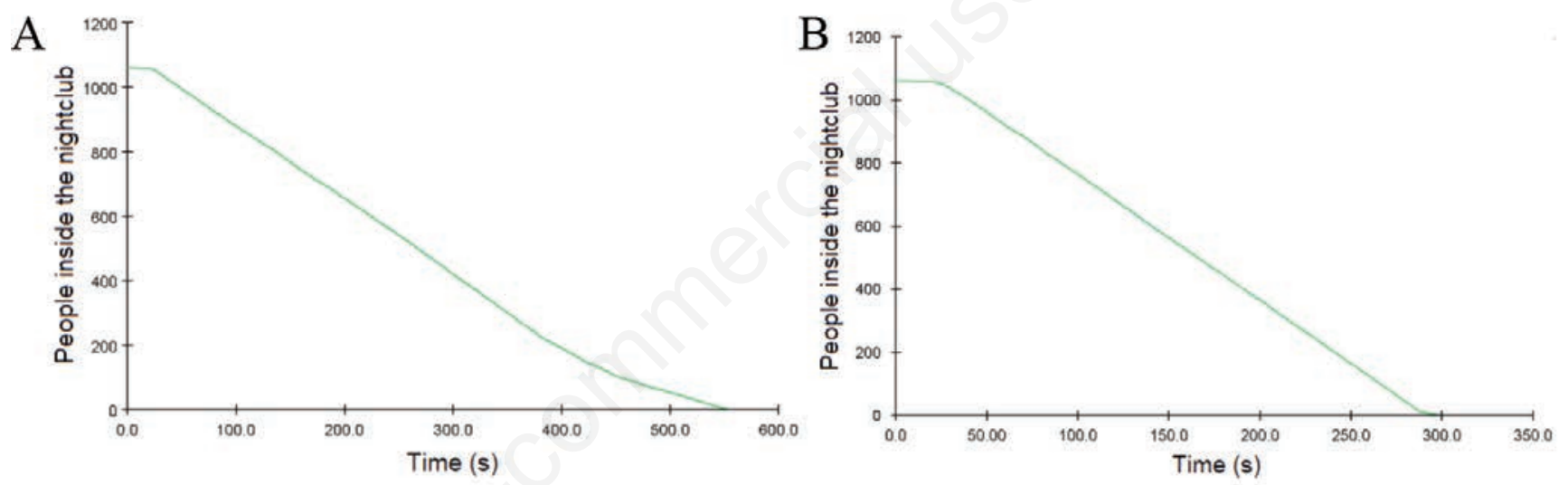

Figure 6. Nightclub evacuation. (A) 1061 people with rails; (B) 1061 people without rails.

A

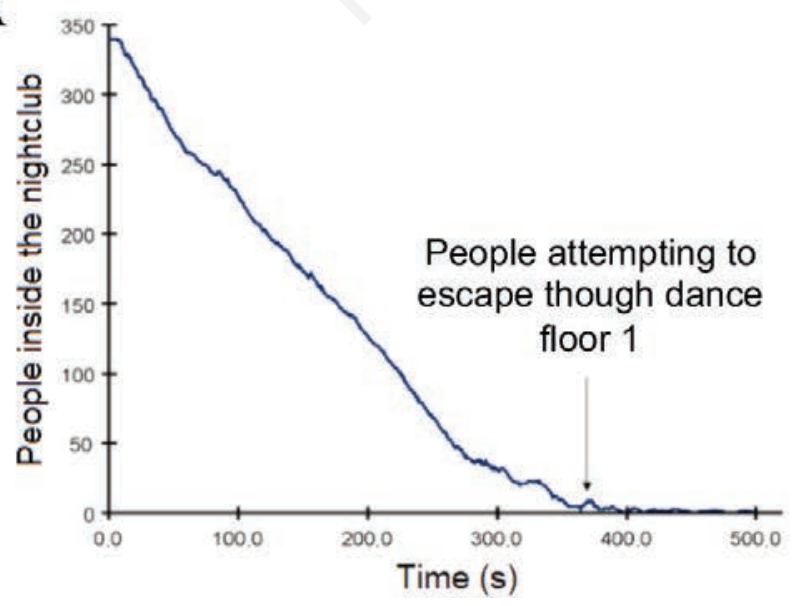

B

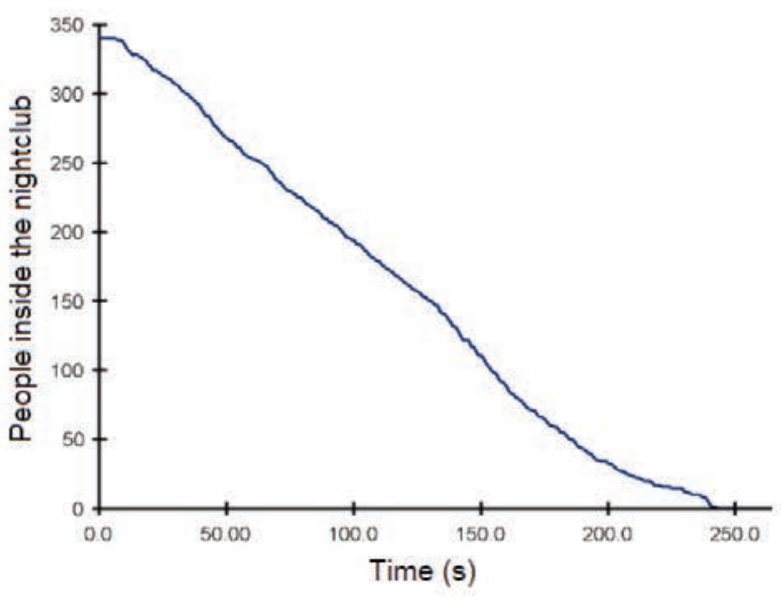

Figure 7. Dance floor 1 evacuation. (A) 1061 people with rails; (B) 1061 people without rails. 
Department of Rio Grande do Sul state. ${ }^{28}$ It can provide better conditions toward quicker escape routes, and other alternative for people that have longer pre-movement time in other areas than the main access.

\section{Conclusions}

Modelling building evacuations is a powerful tool for analyzing and designing emergency exits, although it does not cover every influence factor of real enclosures. It should be carefully interpreted by professionals in the fire safety field. Each simulation will be different and have its own influence factors.

The simulations presented a reduction of nearly $50 \%$ of the total time for evacuating the Kiss nightclub without the rails. It confirmed that the design of emergency doors following regulatory prescriptions for a minimum width, clearance of escape routes to allow a continuous flow, and mainly the maximum capacity of the establishment, provide reasonable time for the occupants to exit safely, which was $200 \mathrm{sec}$ onds in this case. This period, however, could not be enough due to the use of inadequate coating material on the roof and the occupancy. Furthermore, the nightclub was overcrowded, and the escape route was obstructed by control railings, which led to a higher evacuation time. Therefore, a set of factors were responsible for this tragedy.

To have efficiency in the evacuation of all users, fire safety techniques must be applied systemically. Active and passive protection measures are complementary and act together to provide good levels of safety, resulting in the proper escape time. In other words, fire exits will be more effective if foreseen along with the fire alarm, the

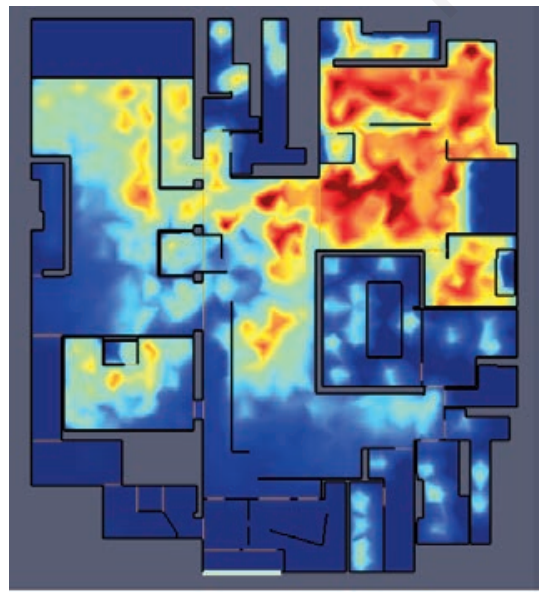

Figure 8. Display of the longest times for evacuation: 1061 people with rails. smoke control systems, the use of sprinklers and the control of coating material's fire reaction.

\section{References}

1. Gill AA, Negrisolo W, de Oliveira AS. Aprendendo com os grandes incêndios. In: Seito A, ed. A segurança contra incêndio no Brasil. São Paulo, SP: Projeto; 2008. pp 19-33.

2. ABNT (Associação Brasileira de Normas Técnicas). Saídas de emergência em edifícios. NBR 9077. Rio de Janeiro; 2001.

3. Gragnani A, de Oliveira AF, Boro D, et al. Response and legislative changes after the Kiss nightclub tragedy in Santa Maria/RS/Brazil: Learning from a largescale burn disaster. Burns 2016;43:343-9.

4. Rodrigues EEC, Rodrigues JPC, da Silva Filho LCP. Comparative study of building fire safety regulations in different brazilian states. J Build Engin 2017;10:102-8.

5. Kobes M, Helsloot I, de Vries B, Post J. Exit choice, (pre-) movement time and (pre-) evacuation behaviour in hotel fire evacuation - Behavioural analysis and validation of the use of serious gaming in experimental research. Proced Engin 2010;3:37-51.

6. São Paulo (Estado). Secretaria de Estado dos Negócios da Segurança Pública. Polícia Militar. Corpo de bombeiros. Instrução técnica n. 11/2015: Saídas de emergência. São Paulo, BR; 2015.

7. Kuligowski E. Predicting Human Behavior During Fires. Fire Technol 2011;49:101-20.

8. Thunderhead Engineering. Verification and validation - Pathfinder. Manhattan, KS; 2015.

9. Zhang X, Li X, Hadjisophocleous G. A probabilistic occupant evacuation model for fire emergencies using Monte Carlo methods. Fire Safety J 2013;58:15-24.

10. Li Z, Tang M, Liang D, Zhao Z. Numerical simulation of evacuation in a subway station. Procedia Engin 2016;135:616-21.

11. Li M, Zhu S, Wang J, Zhou Z. Research on fire safety evacuation in a university library in Nanjing. Proced Engin 2018;211:372-8.

12. Ronchi E, Colonna P, Capote J, et al. The evaluation of different evacuation models for assessing road tunnel safety analysis. Tunnel Underground Space Technol 2012;30:74-8

13. Ronchi E, Uriz F, Criel X, Reilly P. Modelling large-scale evacuation of music festivals. Case Stud Fire Safety 2016;5:119.

14. Ronchi E. Testing the predictive capabili- ties of evacuation models for tunnel fire safety analysis. Safety Sci 2013;59:14153.

15. Conselho Regional De Engenharia e Agronomia Do Rio Grande Do Sul (CREA-RS). Análise do sinistro na Boate Kiss. Porto Alegre; 2013.

16. Mitidieri ML. O comportamento dos materiais e componentes construtivos diante do fogo - reação ao fogo. In: Seito A, ed. A segurança contra incêndio no Brasil. São Paulo, SP: Projeto; 2008. pp 55-75.

17. Vauquelin O, Telle D. Definition and experimental evaluation of the smoke 'confinement velocity' in tunnel fires. Fire Safety J 2005;40:320-30.

18. da Cunha LCL, Martinelli Jr RH. Sistema de controle de fumaça. In: Seito A, ed. A segurança contra incêndio no Brasil. São Paulo, SP: Projeto; 2008. pp 257-275.

19. Gouveia A, Etrusco P. Tempo de escape em edificações: os desafios do modelamento de incêndio no Brasil. Rev Escola Minas 2002;55:257-61.

20. Berto AF. Medidas de proteção contra incêndio: aspectos fundamentais a serem considerados no projeto arquitetônico dos edifícios. Master's Thesis, Universidade de São Paulo, BR; 1991.

21. Moncada JA. Caos o pánico...Qué pasa durante el proceso de evacuación en um incendio? NFPA J Latinoam 2005;4.

22 Kuligowski ED. Human behavior in fire. In: Hurley MJ, ed. SFPE handbook of fire protection engineering. Springer, NY; 2016. pp 2070-2114.

23. de Araujo JMF. Comportamento humano em incêndios. In: Seito A, ed. A segurança contra incêndio no Brasil. São Paulo, SP: Projeto; 2008. pp 93-100.

24. Thunderhead Engineering. Technical reference - Pathfinder. Manhattan, KS; 2013.

25. Grewolls G, Grewolls K. Sensitivity analysis of evacuation simulations. Proc Engin 2014;02:22-6.

26. Guigay GJ, Snorrasson DS. Fire and crowd evacuation modelling in a low ceiling sport arena. Fire and Evacuation Modeling Technical Conference (FEMTC) 2014. Gaithersburg; 2014.

27. Grosshandler W, Bryner N, Madrzykowski D, Kuntz K. Report of the technical investigation of the station nightclub fire. Gaithersburg, MD: National Institute of Standards and Technology, 2005.

28. Rio Grande Do Sul. Secretaria de Estado dos Negócios da Segurança Pública. Polícia Militar. Corpo de bombeiros. Resolução Técnica n. 11/2016: Saídas de emergência. Porto Alegre; 2016. 